\title{
Board Structure and Institutional Ownership at the time of IPO
}

\author{
Suman Neupane \\ Department of Accounting, Finance and Economics, Griffith Business School, Nathan \\ campus, Griffith University, Nathan QLD 4111, Australia, and \\ Biwesh Neupane \\ Department of Accounting and Finance, University of Strathclyde, Scotland G4 OLN, United \\ Kingdom
}

\begin{abstract}
Purpose - The purpose of this paper is to examine the impact of mandatory regulatory provisions on board structure and the influence of such board structure on institutional holdings.

Design/Methodology/Approach - The study uses unique hand-collected data set of Indian IPOs during the 2004-2012 period after the corporate governance reforms with the introduction of Clause 49 in the listing agreements in 2001. Using OLS regression, the paper empirically analyses the determinants of board size and board independence at the time of the IPOs and the influence of such a board structure on shareholdings by domestic and foreign institutional investors.
\end{abstract}

Findings - The authors find that complying with mandatory regulatory provisions does not impede firms from structuring their boards to reflect the firms' advising and monitoring needs. The authors also find that complying with provisions have positive implication for the firm, as firms with greater board independence appear to attract more foreign institutional investors.

Originality/Value - To the authors' best knowledge, this is the first study to examine the issue in a regime where regulation mandates the composition of the board of directors. The paper also extends the literature on institutional holdings by providing evidence on the impact of board structure on institutional ownership at a critical time in a firm's life cycle when concerns for endogeneity for empirical investigations are weaker.

Keywords: Board size, Board independence, Institutional investors, Foreign institutional investors, Indian IPOs

Paper type: Research Paper 


\section{Introduction}

In the wake of major corporate collapses, new legislations and governance codes have emerged around the world and private firms contemplating undertaking public listing are required to meet a number of regulatory requirements. One such regulatory requirement relates to the structure of the board of directors where mandatory provisions have been put in place in a number of countries including the U.S. While there is extensive research on the relation between corporate governance and a firm's financial performance, we still know very little on how firms structure their boards at the time of an initial public offer (IPO). This is particularly true in the context where mandatory regulatory provisions are in place. In this study, we look at two related issues that explore mandatory corporate governance regulations in the context of IPO firms. First, we ask whether mandatory regulations impede firms in structuring their boards at the time of the IPO. We follow this by examining the implication of such mandatory regulations on firm outcomes.

We analyze these two issues by using data from Indian IPO firms issued during the 2004-2012 period. The paper addresses the first issue by examining the impact of mandatory regulation on two fronts of board structure of Indian firms at the time of IPO: (i) board size and (ii) board independence. The period of our study marks an important era of corporate governance reforms in India with the introduction of Clause 49 in the listing agreements in 2001. The clause specifies mandatory provisions on board independence with the fraction of independent directors conditional on whether the chairman of the board is also the CEO or founder (promoter) of the firm [1]. Such regulatory requirements provide us with an ideal setting to examine whether such mandatory regulations assists or impedes firms in structuring their boards at the time of IPO.

We address the second issue by investigating an important outcome associated with IPO offering: the impact of mandatory board structure on institutional ownership in the immediate 
period after the IPO. Prior studies show that board structure, and in particular board independence, has a strong influence on institutional ownership (Chung and Zhang, 2011; Miletkov et al., 2014). Our setting allows us to examine how board structure, one of the most visible dimensions of corporate governance at the time of IPO, influences ownership of institutional investors. Since IPO offers the first opportunity for institutional investors to own shares in newly listed firms, this study also expands our understanding of the factors that attract institutional investors at a time when the concerns of reverse causality are not so relevant.

Several interesting findings emerge from this study. The examination of board structure indicates that the mandatory provision of the regulation is the key determinant of board composition as almost all the firms comply with the provisions of the regulations. However, even after complying the mandatory regulation, we find that both board size and the board composition reflects the advising and monitoring needs of the firm. In other words, our evidence suggests that complying with mandatory regulations does not impede firms from structuring their boards that is consistent with their scope of operation and the monitoring needs. In addition, the results also demonstrate a strong relation between CEO ownership and board structure implying that CEO's influence plays a critical role in the determination of board structure at the time of the IPO.

The investigation on institutional holdings immediately after the IPO reveals, rather surprisingly, that for overall institutional investors, neither board size nor the board independence significantly influences their holdings in IPO firms. However, when we examine institutional holdings separately for domestic and foreign institutional investors, we find a positive and strong relationship between board independence and holdings by foreign institutional investors. The relation between board structure and domestic institutional holdings remains insignificant. Our result suggests that board independence is an important determinant of the foreign institutional ownership and that foreign institutional ownership is higher in firms 
with more independent directors. Since the number of directors is mandated by the regulatory provisions, complying with the provision appears to be beneficial for IPOs firms. Further, consistent with prior studies, we also find evidence of varying investment preferences of domestic and foreign institutional investors.

The paper makes three important contributions to the literature. First, it adds to the relatively sparse literature on the determinants of board structure of IPO firms. To the best of our knowledge, this is the first study to examine the issue in a regime where regulation mandates the composition of the board of directors. This is also one of the first studies from an emerging market which complements the existing evidence from established markets (Baker and Gompers, 2003; Suchard, 2009). The second contribution relates to the literature on institutional ownership and corporate governance. This is one of the few papers that examine the determinants of institutional ownership in the immediate post-IPO period. We extend the literature on institutional holdings (see Ferreira and Matos (2008) and Chung and Zhang (2011)) by providing evidence on the impact of board structure on institutional ownership at a critical time in a firm's life cycle when concerns for endogeneity for empirical investigations are weaker. Third, complementing the findings of Miletkov et al. (2014), we examine the relationship between board structure and domestic as well as foreign institutional investors' participation.

The remainder of this paper is organized as follows. Section 2 briefly discusses the relevant regulations related to corporate governance in India and develops the hypotheses. Section 3 presents the data and descriptive statistics. Sections 4 and 5 discuss the main empirical findings. Finally, Section 6 provides a brief conclusion of the study. 


\section{Regulations and hypotheses development}

\subsection{Regulation on board structure (Clause 49)}

Corporate governance regulations in India have evolved significantly over the last two decades, and it took a major step with the promulgation of Clause 49 of the stock exchange listing agreement in 2001 [2]. The provisions in Clause 49 are related to corporate governance issues, such as composition of board of directors, compensation and disclosures of non-executive directors similar to those of the Sarbanes-Oxley Act and the New York Stock Exchange listing rules. While the provisions of the clause were not intended to apply to all publicly listed firms at the time of introduction in 2001, they were mandatory for private firms seeking to go public. Hence, all our sample IPO firms are subject to the provisions of Clause 49.

Although the regulations do not prescribe on the size of the board per se, there are clear mandatory requirements for board composition. Regulations require that when the chairman of the board is a non-executive director, one third of the board members should comprise of independent directors and when the chairman of the board is an executive director half of the board should comprise of independent directors. However, if the non-executive chairman is a promoter of the company or is related to any promoter or person occupying management positions, at least one-half of the board of the company should consist of independent directors. Thus, while Clause 49 does not require majority of the board members to be independent, it nevertheless mandates the number of independent members on the board. More importantly, if firms merely follow the mandatory provision, board composition would essentially hinge on whether chairman of the board is also the CEO and/or promoter of the firm.

\subsection{Hypotheses Development}

\subsubsection{Impact of regulation on board structure}


The beginning of our sample period marks the introduction of Clause 49 of the listing agreement which mandates the composition of boards for Indian IPO firms. In the context of corporate boards, if regulations are effective in fixing the problem of sub-optimal boards, then we should expect a positive relation between firm characteristics and board structure (Linck et $a l ., 2008)$. While the overall purpose of the regulation is to improve governance and ultimately firm performance, this may not necessarily be the outcome in a mandated regulatory provision. Coles et al. (2008) demonstrate that the optimal board structure is endogenously determined based on the characteristics of the firm and argue that mandated provisions may not necessarily enhance firm value. Likewise, Wang (2014) shows that the board composed of insiders are as effective as board composed of outsiders if CEO is hired from outside of the firm even after the mandatory provision of SOX to have a board composed of majority of independent directors.

If the mandatory regulation does not impede firms from achieving optimal boards, then we should observe a positive relation between firm characteristics and board structure, i.e. firms should find their board structure closely aligned with to their advising and monitoring needs. On the other hand, if regulation drives firms away from their optimal board structure, we should observe a weak or muted relation between firms' advising and monitoring needs and its board structure.

\subsubsection{Board structure and institutional ownership}

Several recent studies demonstrate the relation between various dimensions of corporate governance and institutional ownership by both foreign and domestic investors. Leuz et al. (2010) for U.S. institutions and Ferreira and Matos (2008) for global institutions, for instance, find a negative relation between large block ownership by insiders and institutional holdings 
In studies that are related to our paper, both Chung and Zhang (2011) and Bushee et al. (2014) robustly document a positive relation between institutional holdings and the quality of governance structure.

Miletkov et al. (2014), in the context of listed firms, show that board structure, and in particular board composition, plays a significant role in attracting foreign institutional investors. Thus, based on existing literature it can be argued that the characteristics of board structure should strongly influence institutional holdings at the time of IPO when no other endogenous market based performance measures are available to investors.

However, mandatory regulations on board structure may force firms to sub-optimally structure their boards and therefore reduce the significance of board structure. Further, given the constrains of mandatory regulations, firms may cosmetically comply with the regulation by hiring socially connected directors, thus reducing the significance of outside directors (Jameson et al., 2014). Given that institutional investors are considered to be informed, we may fail to find any relationship between institutional holdings and board structure if mandated provisions force firms to structure their board either sub-optimally or cosmetically.

\section{Data and Sample features}

\subsection{Data}

The sample comprises of 377 IPOs issued and listed on the Bombay Stock Exchange (BSE) and/or the National Stock Exchange (NSE) between 2004 and 2012. Data on boards of directors, pre-IPO ownership, and the IPO firm and offer characteristics were hand-collected from the IPO prospectus. In the analysis of institutional ownership, we lose 14 IPOs due to missing data on institutional ownership. Indian regulations require firms to report their 
ownership structure on a quarterly basis which includes details of ownership by investor categories including promoters and institutional investors. The data on post-IPO institutional ownership, stock returns and trading turnover are drawn from Capitaline Database, which is the one of the leading capital market databases in India. Appendix A provides the definitions of all the variables used in the study.

\section{[Insert Table 1 about here]}

\subsection{Sample features}

Table 1 (Panel A) presents descriptive statistics of IPO firm characteristics. Only about 18\% of 377 Indian IPOs are backed by venture capital (VC) at the time of the offering. This is much lower than the fraction of VC backed IPO firms in the US (Krishnan et al., 2011) but similar to that of Australian IPO firms (Suchard, 2009). We include venture capital backed IPOs as it not only reduces the adverse selection problem but also enhances asset productivity and long term firm performance (Escobari et al., 2016). Both total assets and IPO proceeds show a wide variation in the size of IPO firms. While the overall mean total assets (proceeds) is INR 5,066 $(2,295)$ million, the median IPO firm has total assets (proceeds) of only INR 1,200 (959) million. The average (median) return on asset ( $R O A$ for the full year prior to the IPO) is $8.7 \%$ (7\%). The mean (median) continuously compounded annual stock return and stock volatility (based on weekly returns) are $-0.31(-0.30)$ and $0.08(0.08)$ respectively.

Panel B (Table 1) shows descriptive statistics related to board and CEO characteristics. The statistics show that average board size of Indian IPOs is 7.57 which is lower than that of listed Indian firms (8.02) reported by Jameson et al. (2014). However, it is larger than those reported of US (6.07 reported by Baker and Gompers (2003) ) and Australian IPO firms (5.05 reported by Suchard (2009)). Figure 1(a) presents the empirical distribution of board size of our sample Indian IPO which suggests most boards have around five to 10 directors. The average 
proportion of outside directors is $47 \%$ which is slightly less than the $50.6 \%$ of listed Indian firms reported by Jameson et al. (2014). The distribution of the fraction of outsiders in the board is graphically presented in Figure 1(b).

The mean CEO ownership is $22 \%$ which is higher than that of Australian IPOs $(18.53 \%)$ reported by Suchard (2009). The average age of CEO is 47.81 years with average tenure of 11.22 years. The tenure of the CEOs in Indian IPO firms is much higher than that of both US (7.19 years reported by Baker and Gompers (2003)) and Australian IPO firms (4.78 years reported by Suchard (2009)). Further, there are 58 firms (about 15\% of the total IPO) with CEOs older than 60 years.

Panel C presents statistics on ownership characteristics. Following Chung and Zhang (2011) we measure ownership as the percentage of shares to the total number of shares outstanding. The statistics reveal that the pre-IPO holdings of an average promoter (founding owner) is $83 \%$ which reduces to $58 \%$ after IPO. This is slightly higher than the $52.4 \%$ of listed Indian firms reported by Jameson et al. (2014). Following Chen et al. (2006), we also analyse the top promoters' holdings and find that average top promoter holds $41.35 \%$ of equity. Whereas, the average institutional ownership immediately after the IPO is $14.09 \%$ which drops to $10.09 \%$ by the end of the first quarter. In general, the institutional ownership remains relatively steady during the next 3 quarters within the first year of listing.

\section{The determinants of board structure}

As discussed earlier, if mandatory regulations do not impede firms from attaining an optimal board, then we should see a positive relation between board size and composition and the advising and monitoring needs of the firm. To examine the determinants, we regress board size and board independence against set of explanatory variables using equation (1). Since the dependent and independent variables used in our study is at the time of IPO, the variables do 
not change over time and by firm. Using cross sectional data at the time of IPO reduces the potential serial correlation in the error term. Moreover, since the board structure at the time of IPO are predetermined and institutional investors cannot influence the board structure, the issues of endogeneity are significantly weaker. In the following paragraphs, we discuss the choice of all these variables included in our analysis.

\section{Board Size/Board Composition}

$$
\begin{aligned}
& =\alpha+\beta_{1} \text { Total Assets }+\beta_{2} \text { Firm Age }+\beta_{3} \text { Debt }+\beta_{4} \text { Cash Holdings } \\
& +\beta_{5} \text { Market to book }+\beta_{6} \text { ROA }+\beta_{7} \text { CEO Ownership }+\beta_{8} \text { CEO Tenure } \\
& +\beta_{9} \text { CEO age }+\beta_{10} \text { CEO Age } \\
& >60+\beta_{n} \text { Industy and Year Dummies }+\varepsilon
\end{aligned}
$$

Fama and Jensen (1983) state that the board's role is to provide the CEO with advice and access to information and resources, as well as to ratify and monitor senior managers' decisions. The larger and more complex the firm is, the greater will be the firm's advising needs. Accordingly, a number of prior studies suggest that both board size and the size of outsiders is positively related to firm size and complexity of operation. Boone et al. (2007) refer to this view as the scope of operation hypothesis which suggests that growing firms will seek new members to oversee managers' performance. We use total assets to proxy for firm size and firm age and debt to proxy for firm complexity.

An alternative view of board size and composition involves the analysis of boards' monitoring role. Raheja (2005) argues that as the benefits (costs) of monitoring increase, boards will do

more (less) monitoring leading to more (less) outsiders and larger (smaller) boards. Thus, optimal boards will employ large numbers of outside directors, and be larger in overall size, when managers' private benefits are high and the cost of monitoring is low. Boone et al. (2007) consider this as the monitoring hypothesis and we use cash holdings as a proxy for the benefits 
of monitoring and market to book ratio and CEO ownership to proxy for a firm's degree of information asymmetry.

A third view of the board looks at the power and characteristics of the CEO. Hermalin and Weisbach (2003) argue that CEOs with high power can bargain with outside directors for a smaller board with fewer outsiders, or place affiliated outsiders in open board positions. Boone et al. (2007) consider this as the negotiation hypothesis and there is considerable prior empirical support showing a strong negative relationship between CEO influence and board size and composition (Guest, 2008). We use ROA, CEO ownership and CEO tenure as proxy for CEO influence. Hermalin and Weisbach (2003) also argue that issues relating to succession can influence board size and composition, particularly when the CEO is closer to retirement. They argue that as a CEO approaches retirement, the firm adds insiders to the board as part of the succession process. Baker and Gompers (2003) find that the fraction of inside directors is higher when the CEO is over 60 and near retirement. We include CEO age and an indicator variable of CEO approaching retirement to proxy for the succession process. Definitions of all the variables are available in Appendix A. Appendix B presents the expected signs and the source of all the determinants.

\subsection{Board Size}

In this section, we examine the determinants of the board size for our sample of 377 Indian IPOs. Since all the firms have complied with the mandatory regulation on board composition at the time of IPO, it will be interesting to observe whether complying with mandatory provisions impede firms from attaining optimal board size. The result of the OLS regression analysis, based on equation (1), is shown in Table 2. The dependent variable in all the specifications is the size of the board measured by the number of board members. All models/specifications control for industry and year fixed effects. Heteroskedasticity adjusted robust $t$-statistics are reported in parenthesis. 


\section{[Insert Table 2 about here]}

Specifications $(1-3)$ separately show the influence of advising role, monitoring role and CEO characteristics on board size; specification (4) combines all the variables together. Specification (1) shows that the coefficients of all the variables bear the expected sign, with total assets and firm age statistically significant at the less than 5\% level. In specification (2) CEO ownership is negative and statistically significant and in specification (3), CEO ownership is negatively related and CEO Age $>60$ is positively related (both significant) to the board size. In specification (4), we find that total assets, firm age, cash holdings, CEO ownership and CEO Age $>60$ remain statistically significant. Our results indicate that board size is indeed correlated with the scope and complexity of firms' operations. Further, the significant positive coefficient of cash holdings suggests that the benefit of monitoring also plays a role in determining the size of the board. Overall, this indicates that complying with the mandatory provisions of the regulation does not impede firms from structuring an optimal board size.

The significant negative coefficient of CEO ownership is consistent with both the monitoring as well as the CEO influence (negotiation) hypothesis. However, this relationship, in the context of Indian IPOs, is possibly a reflection of influence (negotiation) rather than monitoring. Baker and Gompers (2003) argue that an IPO is an opportune time to examine the negotiation hypothesis as the CEO's influence comes into play at such times. A large number of these Indian IPO firms are run by families who have major controlling stake in the firm at the time of the IPO. The power derived from this substantial holding is more likely to be used by CEOs to influence board membership. Given that CEOs own a significant fraction of the firm's equity, the negative relation between board size and CEO ownership is also consistent with Linck et al. (2008) ownership incentives hypothesis. Finally, the positive coefficient of CEO $>60$ is not surprising as board membership may be a part of the process of grooming future CEOs as argued by Baker and Gompers (2003). 


\subsection{Board independence}

Next we examine the determinants of board independence of Indian IPO firms where minimum proportion of outside directors is prescribed by the regulation. Appendix A present the definitions of all the variables and Appendix B presents the source as well as expected sign of all the determinant variables. The results are reported in Table 3. All regression models include industry and year fixed effects. Heteroskedasticity adjusted robust $t$-statistics are reported in parenthesis.

\section{[Insert Table 3 about here]}

The dependent variable in all the specifications is the number of outsiders in the board. We use number of independent directors (outsiders), rather than percentage of independent directors because a large proportion of the IPO firms have exactly 50 per cent as outsiders in the board causing only a limited variation in the values of the dependent variable. Specification (1) includes proxies for advising roles, specification (2) includes proxies for monitoring roles, specification (3) includes only CEO characteristics, both firm and CEO characteristics are included in specification (4).

The results are similar to those reported for board size. Specification (1) shows that the number of outsiders is positively and significantly related to total assets; specification (2) shows that CEO ownership is negatively and cash holdings is positively related to the number of outsiders on the board. In specification (3), we find that CEO ownership is negatively related and CEO Age $>60$ is positively related to outsider size. In specification (4), we find that total assets, cash holdings, CEO ownership and CEO age>60 remain statistically significant and are the major determinants of board independence. 
Our results are in line with those reported in previous studies (for example, Boone et al. (2007)) and indicate that outsider size is also correlated with the scope and complexity of firms' operation. The significant and positive relation between firms' cash holdings and board independence provide support for monitoring hypothesis. The significant and negative relationship between CEO ownership and board independence provide support for both monitoring and CEO influence (negotiation) hypothesis. Given most of the firms are family owned and controlled at the time of IPO; CEO may have substantial influence on appointment of independent board of directors. Hence, this relationship between CEO ownership and outsider size is possibly a reflection of influence (negotiation hypothesis) rather than monitoring. The relationship is also consistent with ownership incentives hypothesis of (Linck et al., 2008) who suggest that independence is decreasing with insider incentive alignment. Overall, our results suggest that Indian IPO firms are able to avoid sub-optimal board structure despite complying with the mandatory regulation on board composition.

\section{The board structure and institutional share ownership}

As the future performance of the firm is likely to depend on the quality of its governance, the investment and shareholding decisions of investors is likely to be guided by the composition/quality of the board. This section examines the implications of the information contained on the composition of the Indian IPO firms' board on the ownership of institutional investors at the time of IPOs as well as in four quarters immediately after the completion of IPO.

\subsection{Overall Institutional Share ownership}


To examine the role of board structure of IPO firms on institutional ownership, we consider several variables that have been associated with institutional holdings as shown in equation (2). As in equation (1), the dependent used in our study is at each quarter after IPO and the independent variables is at the time of IPO, the variables do not change over time and by firm. Due to cross-sectional nature of data, there are no potential serial correlational in the error term and the issue of endogeneity are significantly weaker in this setting.

\section{Institutional Holdings}

$$
\begin{aligned}
& =\alpha+\beta_{1} \text { Board Independence }+\beta_{2} \text { Board Size }+\beta_{3} \text { Dual } \\
& +\beta_{4} \text { Top Promoter }+\beta_{5} \text { Post IPO Promoters'Holding } \\
& +\beta_{6} \text { VC Backed }+\beta_{7} \text { Market Capitalization }+\beta_{8} \text { Book to makrket } \\
& +\beta_{9} \text { Firm Age }+\beta_{10} \text { ROA }+\beta_{11} \text { Cash } \\
& +\beta_{12} \text { Debt }+\beta_{13} \text { Stock Return }+\beta_{14} \text { Stock Volatility } \\
& +\beta_{15} \text { Trading Turnover }+\beta_{n} \text { Industy and Year Dummies }+\varepsilon
\end{aligned}
$$

The main variables of concern for this analysis are related to board structure - namely board independence and the size of the board [3]. As an additional aspect of the board structure, we also include a dummy variable representing the CEO duality. Following Ferreira and Matos (2008) and Chung and Zhang (2011) we include a number of control variables that have been associated with institutional ownership. Accordingly, to control for insiders' ownership characteristics the fraction of shares owned by top promoter (Chen et al., 2006) and the fraction of shares held by promoters in the post-IPO period (Ferreira and Matos, 2008) are included [4]. A dummy variable representing the VC backed IPOs, market capitalization of the firm, bookto-market ratio, firm's age, ROA, cash holdings, debt ratio, stock return stock volatility [5] and trading turnover are also included as control variables. The definition of all these variables is 
presented in Appendix A, while the source and the expected sign of the variables are shown in Appendix C.

The results of OLS regression analysis are presented in Table 4 where the dependent variable, institutional holdings, is defined as the fraction of shares owned by institutional investors relative to the total outstanding shares of the IPO firm. All specifications control for industry and year fixed effects and the reported t-statistics are adjusted for heteroskedasticity. Specification (1) examines institutional ownership at the end of the first quarter, specification (2) at the end of the second quarter and specification (3) at the end of the fourth quarter. Since prior studies suggest that investors flip their IPO allocation in the post-listing period (Ellis, 2006), we extend the time frame to the first year of listing. Further, by limiting the analysis to only the first year of listing helps us to avoid concerns of reverse causality as discussed in Chung and Zhang (2011).

\section{[Insert Table 4 about here]}

Surprisingly, the results in all three specifications show that neither board independence nor board size appear to influence institutional holdings. Overall, the result is not only inconsistent with some recent studies (Bushee et al., 2014; Miletkov et al., 2014), it also suggests that institutional investors do not consider board composition as a relevant firm level measure of corporate governance in the context of Indian firms. In the next section, we will examine institutional holdings by foreign and domestic investors to see if the result holds for both the categories of institutional investors.

Among the variables representing insiders' ownership, consistent with the findings of Ferreira and Matos (2008), the estimates reveal significant negative relationship between post IPO promoters' holding and institutional ownership. Since post IPO promoter's holding reflects the fraction of shares held by insiders, it is apparent that institutional investors invest less in firms 
with large insider holdings. The role of other control variables is also consistent with the findings reported in prior studies. The evidence shows that the institutional investors generally prefer and invest more on larger firms, those backed by venture capitalists, higher firm's cash holding and stock return. However, the institutional shareholding is found to be inversely related to stock volatility. The estimates also suggest an inverse relation between trading turnover and institutional ownership [6]. A closer inspection shows that this relationship is driven by the fact that trading turnover is substantially higher in smaller firms in the immediate post-listing period. This negative relationship, however, becomes generally weaker and economically less meaningful over time. Conversely, the relationship between institutional ownership and stock return/volatility becomes stronger over time.

\subsection{Foreign and domestic institutional investors}

In this section, we examine whether the composition of board structure has differing impact on the holdings of domestic and foreign institutional investors. Several prior studies show that the investment preferences of foreign and domestic institutional investors vary significantly (Ferreira and Matos, 2008; Chung and Zhang, 2011). Prior studies also suggest that while domestic institutional investors have informational advantage in their home markets, foreign institutional investors are more likely to have superior investment experience and expertise.

The results of OLS regression (based on equation (2)) is presented in Table 5 where the dependent variable in specification $(1-3)$ is the fraction of shares owned by domestic institutional and the dependent variable in specification $(4-6)$ is fraction of shares owned by foreign institutional in first quarter, second quarter and fourth quarter respectively.

\section{[Insert Table 5 about here]}

While all the three aspects of board composition remain insignificant for domestic institutional investors, we find that the coefficient on board independence is positive and statistically 
significant for holdings by foreign institutional investors. We also find that the economic and statistical significance of board independence on foreign institutional holdings increases over time. This finding on the investment behaviour of foreign institutional investors is consistent with Miletkov et al. (2014), who find that board independence is an important determinant of the level of foreign institutional ownership and that foreign institutional ownership is higher in firms with more independent directors. The result also suggests that as domestic institutional investors may have other avenues of information, on account of their information advantage, they do not rely on the information contained on the board composition in making their investment decisions. On the other hand, the publicly available information on board composition represents one of the few anchors that foreign institutional investors have in making their investment decisions.

The estimates on various control variables reveal that while the ownership of domestic as well as foreign institutional investors is negatively related to the post-IPO promoters' holdings, the economic significance of this variable is higher for foreign institutional than domestic institutional investors. Likewise, we also find that foreign investors have a stronger preference for larger firms than domestic investors. Domestic investors show a strong preference for firms with large cash holdings, while foreign institutional investors appear to be attracted to firms with high recent stock returns. Both foreign and domestic institutional investors appear to avoid firms with high price volatility.

\section{Conclusions}

Using a unique hand-collected data set of Indian IPOs issued during the 2004-2012 period, this paper examines the influence of mandatory provisions on board structure as well as the impact of such board structure on institutional holdings in the immediate post-IPO period. The sample period represents an important era of corporate governance reforms in India with the 
introduction of a number of mandatory provisions, including the composition of the board of directors for firms seeking to go public. In this background, the paper empirically analyses the determinants of board size and board independence at the time of the IPOs. Further, the influence of such a board structure on shareholdings by institutional investors is also extensively analyzed.

Our results show that while almost all the firms follow the mandatory provisions on board structure, complying with the provisions does not impede firms from structuring their boards that reflect the firms' advising and monitoring needs. Board size and size of outsiders bear a positive relationship with total assets and cash holdings of the IPO firm consistent with the suggestion that board size as well as board independence is a reflection of the firm's advising and monitoring needs. We further find that CEO influence is a major determinant of board size and board composition for Indian firms at the time of the IPO as we find strong negative relationship between CEO ownership and board size/outsider size. An extensive analysis of institutional ownership immediately after the IPO demonstrates a lack of significant relation between board structure and shareholdings of the overall institutional investors. However, when we examine the holdings separately for domestic and foreign investors, we find a positive and strong relation between board independence and the holdings by foreign institutional investors. Our result suggests that board independence is an important determinant of the foreign institutional ownership and that foreign institutional ownership is higher in firms with more independent directors.

Notes:

\footnotetext{
${ }^{1}$ We discuss this regulation in some detail in section 2.
} 
${ }^{2}$ Chakrabarti et al. (2008) provide a detailed description of the evolution of corporate governance in India.

${ }^{3}$ For robustness, we ran all the analyses using the number of outsiders on the board. Results are qualitatively similar and can be provided upon request.

${ }^{4}$ Since promoters have a lock-in period of 3 years, we use the promoters' holdings immediately after IPO as post IPO promoters' holding in all our analyses.

${ }^{5}$ Our results are qualitatively similar when we use the first three month stock return and stock volatility measures.

${ }^{6}$ We also re-run all the specifications by using annual figures and our results are qualitatively similar. 


\section{Appendix A}

\section{Description of variables}

\section{Variable \\ IPO Firm/Offer Characteristics}

\begin{tabular}{|c|c|}
\hline VC Backed & IPO firms that are backed by a venture capitalists. \\
\hline Total Assets & $\begin{array}{l}\text { Book value of total assets (log value is used in } \\
\text { regressions). }\end{array}$ \\
\hline Proceeds & Offer price multiplied by the number of shares offered. \\
\hline Market Capitalization & $\begin{array}{l}\text { Total market capitalization of the firm at offer price (log } \\
\text { value is used in regressions). }\end{array}$ \\
\hline Firm Age & $\begin{array}{l}\text { Difference between a firm's IPO year and the founding } \\
\text { year (log of } 1 \text { plus the firm's age is used in regressions). }\end{array}$ \\
\hline Cash & Percentage of cash holdings to total sales. \\
\hline Market-to-Book & $\begin{array}{l}\text { Ratio of book value of total debt plus market value of } \\
\text { equity (calculated at offer price) divided by total assets at } \\
\text { the time of IPO. Book-to-market is the inverse of market- } \\
\text { to-book. }\end{array}$ \\
\hline Debt & Ratio of total debt to total assets. \\
\hline ROA & $\begin{array}{l}\text { Return on total assets for the full year prior to the year of } \\
\text { the IPO. }\end{array}$ \\
\hline Stock Return & $\begin{array}{l}\text { Continuously compounded annual return based on } \\
\text { monthly returns. For first, second and fourth quarter } \\
\text { institutional ownership regressions, we use the first three } \\
\text { months, six months and twelve months monthly returns } \\
\text { respectively. We exclude first day return. }\end{array}$ \\
\hline Stock Volatility & $\begin{array}{l}\text { Standard deviation of weekly returns. For first, second } \\
\text { and fourth quarter institutional ownership regressions, } \\
\text { we use the standard deviation of weekly returns for first } \\
\text { three, six and twelve months respectively. We exclude } \\
\text { the first day return. }\end{array}$ \\
\hline Trading Turnover & $\begin{array}{l}\text { Ratio of total number of shares traded to total shares } \\
\text { outstanding. For first, second and fourth quarter } \\
\text { institutional ownership regressions, we use the three } \\
\text { month, six month and one year trading volume } \\
\text { respectively. We exclude the trading volume on the first } \\
\text { day of listing }\end{array}$ \\
\hline
\end{tabular}

Definition

Board and CEO Characteristics 


\begin{tabular}{ll}
\hline Board Size & $\begin{array}{l}\text { Number of people on the board. } \\
\text { Outsider Size }\end{array}$ \\
Bumber of independent directors on the board. \\
$\begin{array}{l}\text { Number of independent directors divided by total number } \\
\text { of board members. }\end{array}$ \\
A dummy variable which equals 1 if COE and chairman \\
positions is the same person and 0 otherwise.
\end{tabular}




\section{Appendix B}

Board Structure Variables: Expected Sign and Source

\begin{tabular}{|c|c|c|c|}
\hline \multirow[b]{2}{*}{ Variables } & \multicolumn{2}{|c|}{ Expected Sign } & \multirow[b]{2}{*}{ Source } \\
\hline & $\begin{array}{l}\text { Board } \\
\text { Size }\end{array}$ & $\begin{array}{c}\text { Board } \\
\text { Independence }\end{array}$ & \\
\hline Total Assets & + & + & $\begin{array}{l}\text { Baker and Gompers (2003); Boone et } \\
\text { al. (2007); Guest (2008) }\end{array}$ \\
\hline Firm Age & + & + & $\begin{array}{l}\text { Baker and Gompers (2003); Boone et } \\
\text { al. (2007);Guest (2008) }\end{array}$ \\
\hline Debt & + & + & Guest (2008) \\
\hline Cash & + & + & $\begin{array}{l}\text { Baker and Gompers (2003); Boone et } \\
\text { al. (2007); Guest (2008) }\end{array}$ \\
\hline Market-to-Book & - & - & $\begin{array}{l}\text { Boone et al. (2007); Linck et al. } \\
\text { (2008) }\end{array}$ \\
\hline $\mathrm{ROA}$ & - & - & Guest (2008); Linck et al. (2008) \\
\hline CEO Ownership & - & - & $\begin{array}{l}\text { Boone et al. (2007); Linck et al. } \\
\text { (2008) }\end{array}$ \\
\hline CEO Tenure & - & - & $\begin{array}{l}\text { Baker and Gompers (2003); Boone et } \\
\text { al. (2007) Linck et al. (2008) }\end{array}$ \\
\hline CEO Age & - & - & $\begin{array}{l}\text { Baker and Gompers (2003); Linck et } \\
\text { al. (2008) }\end{array}$ \\
\hline CEO Age $>60$ & + & + & $\begin{array}{l}\text { Baker and Gompers (2003); Linck et } \\
\text { al. (2008) }\end{array}$ \\
\hline
\end{tabular}




\section{Appendix C}

Institutional Ownership Variables: Expected Sign and Source

\begin{tabular}{|c|c|c|}
\hline Variables & $\begin{array}{l}\text { Expected } \\
\text { Sign }\end{array}$ & Source \\
\hline Board Size & + & $\begin{array}{l}\text { Coles et al. (2008); Bushee et al. (2014); Jameson et } \\
\text { al. (2014) }\end{array}$ \\
\hline Board independence & + & $\begin{array}{l}\text { Coles et al. (2008); Bushee et al. (2014); Jameson et } \\
\text { al. (2014) }\end{array}$ \\
\hline Dual & - & Bushee et al. (2014) \\
\hline Top Promoter & - & Chen et al. (2006); Ferreira and Matos (2008); \\
\hline $\begin{array}{l}\text { Post-IPO Promoters' } \\
\text { Holding }\end{array}$ & - & Ferreira and Matos (2008) \\
\hline VC Backed & + & Field and Lowry (2009) \\
\hline Market Capitalization & + & $\begin{array}{l}\text { Bushee et al. (2014); Ferreira and Matos (2008); } \\
\text { Chung and Zhang (2011) }\end{array}$ \\
\hline Book-to-Market & + & Ferreira and Matos (2008); Bushee et al. (2014) \\
\hline Firm Age & + & Field and Lowry (2009); Chung and Zhang (2011) \\
\hline ROA & + & $\begin{array}{l}\text { Ferreira and Matos (2008); Chung and Zhang } \\
\text { (2011) }\end{array}$ \\
\hline Cash & + & Ferreira and Matos (2008) \\
\hline Debt & + & Chung and Zhang (2011) \\
\hline Stock Return & + & $\begin{array}{l}\text { Ferreira and Matos (2008); Chung and Zhang } \\
\text { (2011) }\end{array}$ \\
\hline Stock Volatility & - & Bushee et al. (2014) \\
\hline Trading Turnover & + & $\begin{array}{l}\text { Ferreira and Matos (2008); Chung and Zhang } \\
\text { (2011); Bushee et al. (2014) }\end{array}$ \\
\hline
\end{tabular}




\section{References}

Baker, M. and Gompers, P. A. (2003) "The Determinants of Board Structure at the Initial Public Offering", Journal of Law and Economics, Vol. 46 No. 2, pp. 569-598.

Boone, A. L., Casares Field, L., Karpoff, J. M. and Raheja, C. G. (2007) "The determinants of corporate board size and composition: An empirical analysis", Journal of Financial Economics, Vol. 85 No. 1, pp. 66-101.

Bushee, B. J., Carter, M. E. and Gerakos, J. (2014) "Institutional investor preferences for corporate governance mechanisms", Journal of Management Accounting Research, Vol. 26 No. 2, pp. 123-149.

Chakrabarti, R., Megginson, W. L. and Yadav, P. K. (2008) "Corporate Governance in India", Journal of Applied Corporate Finance, Vol. 20 No., pp. 59-72.

Chen, G., Firth, M., Gao, D. N. and Rui, O. M. (2006) "Ownership structure, corporate governance, and fraud: Evidence from China", Journal of Corporate Finance, Vol. 12 No. 3 , pp. 424-448.

Chung, K. H. and Zhang, H. (2011) "Corporate governance and institutional ownership", Journal of Financial and Quantitative Analysis, Vol. 46 No. 01, pp. 247-273.

Coles, J. L., Daniel, N. D. and Naveen, L. (2008) "Boards: Does one size fit all?", Journal of Financial Economics, Vol. 87 No. 2, pp. 329-356.

Ellis, K. (2006) "Who trades IPOs? A close look at the first days of trading", Journal of Financial Economics, Vol. 79 No. 2, pp. 339-363.

Escobari, D., Serrano, A. and Johnson, D. (2016) "Reducing asymmetric information in venture capital backed IPOs", Managerial Finance, Vol. 42 No. 6.

Fama, E. F. and Jensen, M. C. (1983) "Separation of ownership and control", Journal of Law and Economics, Vol. 26 No., pp. 301-325.

Ferreira, M. A. and Matos, P. (2008) "The colors of investors' money: The role of institutional investors around the world", Journal of Financial Economics, Vol. 88 No. 3, pp. 499-533.

Field, L. and Lowry, M. (2009) "Institutional versus individual investment in IPOs: the importance of firm fundamentals", Journal of Financial and Quantitative Analysis, Vol. 44 No. 3, pp. 489-516.

Guest, P. M. (2008) "The determinants of board size and composition: Evidence from the UK", Journal of Corporate Finance, Vol. 14 No. 1, pp. 51-72.

Hermalin, B. E. and Weisbach, M. S. (2003) "Boards of directors as an endogenously determined institution: a survey of economic literature", FRBNY Economic Policy Review. pp. 7-26. 
Jameson, M., Prevost, A. and Puthenpurackal, J. (2014) "Controlling shareholders, board structure, and firm performance: Evidence from India", Journal of Corporate Finance, Vol. 27 No., pp. 1-20.

Krishnan, C., Ivanov, V. I., Masulis, R. W. and Singh, A. K. (2011) "Venture capital reputation, post-IPO performance, and corporate governance", Journal of Financial and Quantitative Analysis, Vol. 46 No. 05, pp. 1295-1333.

Leuz, C., Lins, K. V. and Warnock, F. E. (2010) "Do foreigners invest less in poorly governed firms?", Review of Financial Studies, Vol. 23 No. 3, pp. 3245-3285.

Linck, J. S., Netter, J. M. and Yang, T. (2008) "The determinants of board structure", Journal of Financial Economics, Vol. 87 No. 2, pp. 308-328.

Miletkov, M. K., Poulsen, A. B. and Wintoki, M. B. (2014) "The role of corporate board structure in attracting foreign investors", Journal of Corporate Finance, Vol. 29 No., pp. 143-157.

Raheja, C. G. (2005) "Determinants of board size and composition: a theory of corporate boards", Journal of Financial and Quantitative Analysis, Vol. 40 No., pp. 283-306.

Suchard, J.-A. (2009) "The impact of venture capital backing on the corporate governance of Australian initial public offerings", Journal of Banking \& Finance, Vol. 33 No. 4, pp. 765-774.

Wang, Y. (2014) "Monitoring CEOs: can insider-dominated boards do a good job?", Managerial Finance, Vol. 40 No. 4, pp. 355-375.

\section{Corresponding Author}

Suman Neupane can be contacted at: s.neupane@griffith.edu.au 
Figure 1(a): Distribution of board size

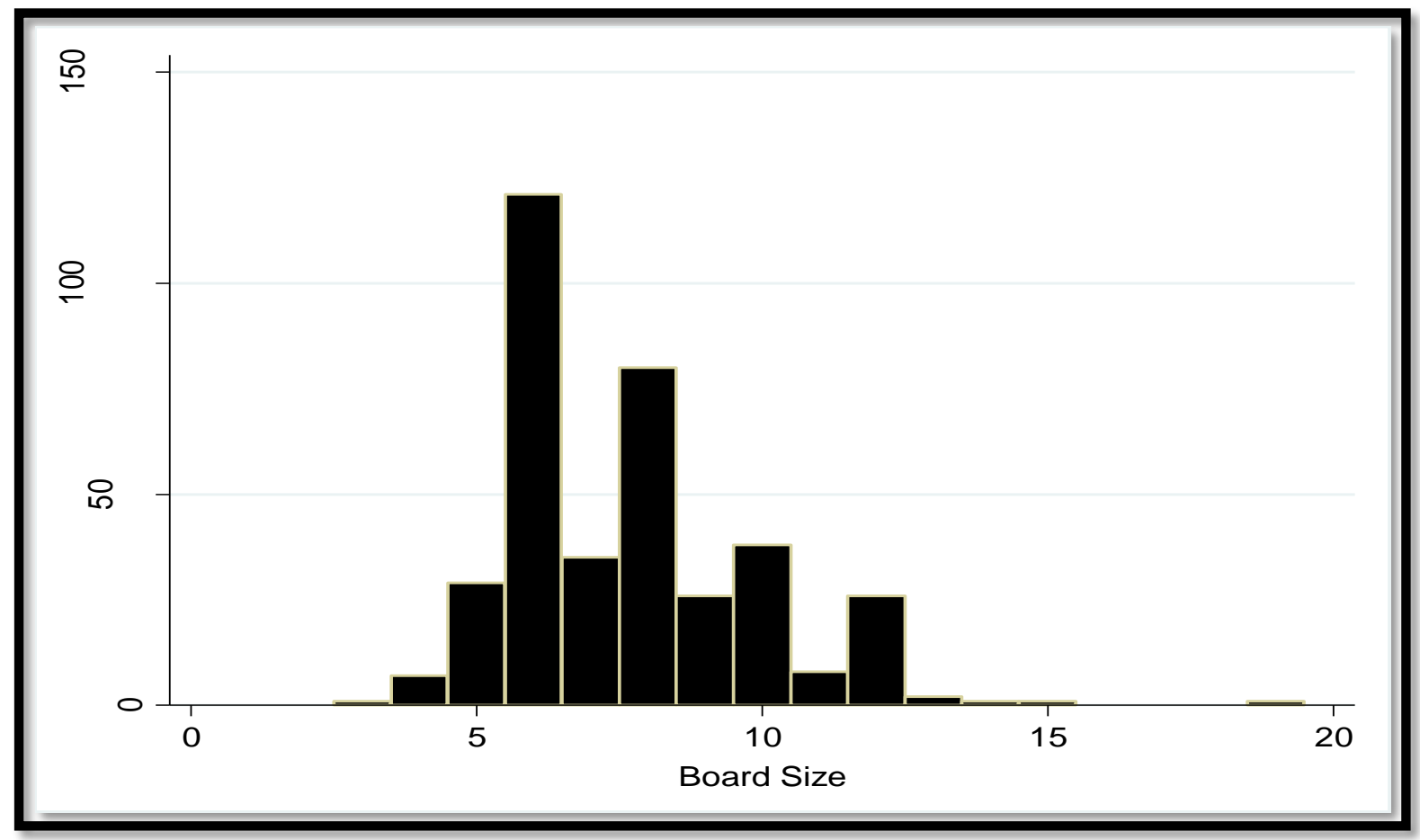

Figure 1(b): Distribution of the fraction of independent directors

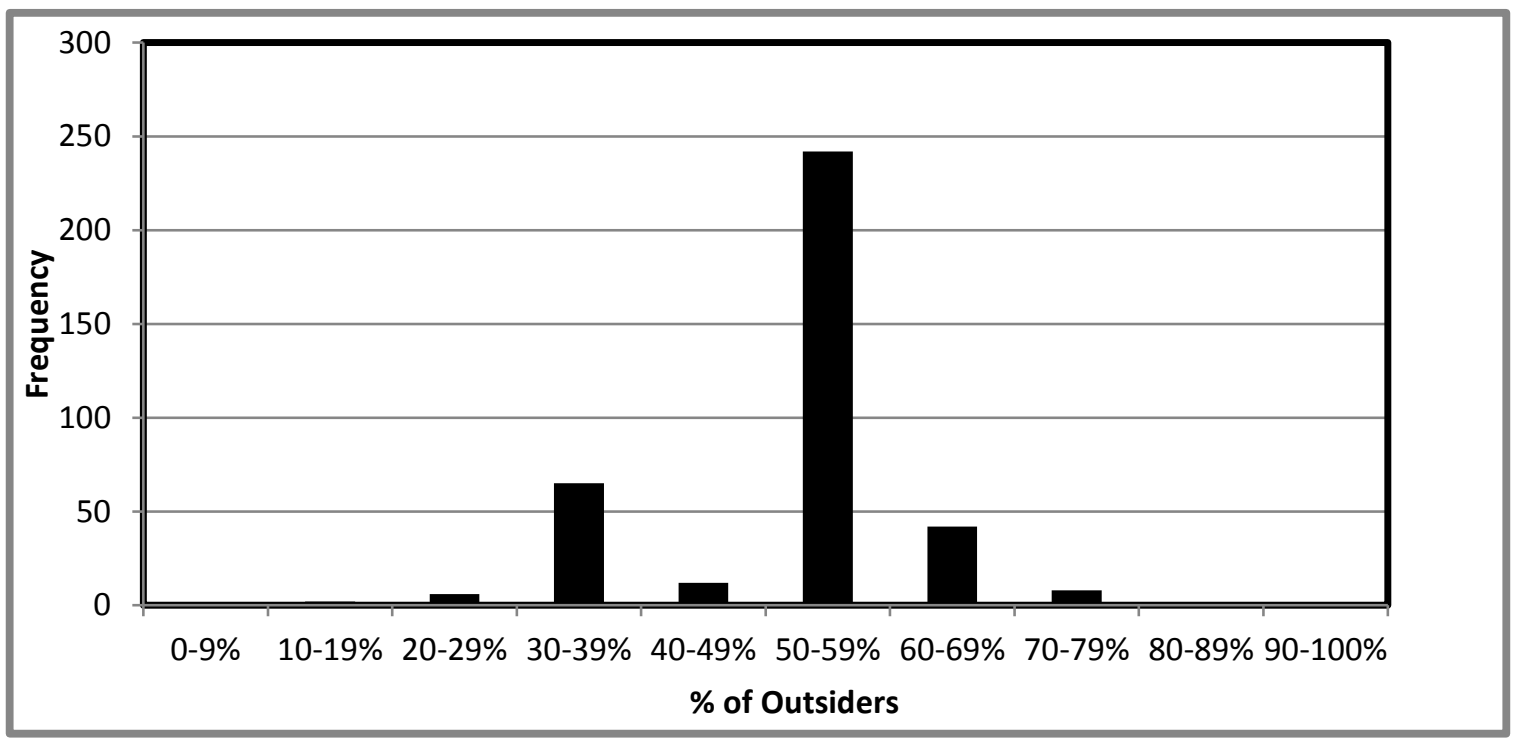


Table 1: Descriptive Statistics

\begin{tabular}{|c|c|c|c|c|c|c|c|}
\hline Variables & Mean & Median & $\begin{array}{l}25 \text { th } \\
\text { Pctl }\end{array}$ & 75 Pctl & $\begin{array}{l}\text { Std } \\
\text { dev }\end{array}$ & Max & Min \\
\hline Number of IPOs & 377 & & & & & & \\
\hline Number of VC Backed IPOs & 68 & & & & & & \\
\hline \multicolumn{8}{|l|}{ Panel A: Firm Characteristics } \\
\hline Total Assets (INR mill) & 5,066 & 1,200 & 561 & 3,858 & 12,949 & 154,856 & 70 \\
\hline Proceeds (INR mill) & 2,295 & 959 & 432 & 1,710 & 6,025 & 91,875 & 60 \\
\hline Market Capitalization (INR mill) & 18,389 & 2,946 & 1,270 & 9,570 & 75,914 & 895,037 & 166 \\
\hline Firm Age & 14.21 & 12.03 & 8.04 & 16.70 & 10.52 & 92.06 & 0.67 \\
\hline Cash & 0.03 & 0.01 & 0.00 & 0.02 & 0.16 & 2.69 & 0.00 \\
\hline Book-to-Market & 0.67 & 0.46 & 0.28 & 0.74 & 1.19 & 20.16 & 0.01 \\
\hline Debt & 0.57 & 0.61 & 0.45 & 0.73 & 0.22 & 1.18 & 0.00 \\
\hline ROA & 0.08 & 0.07 & 0.04 & 0.12 & 0.14 & 1.60 & -0.65 \\
\hline Market Return & 0.04 & 0.05 & 0.01 & 0.09 & 0.07 & 0.29 & -0.23 \\
\hline Market Volatility & 0.01 & 0.01 & 0.00 & 0.02 & 0.01 & 0.04 & 0.00 \\
\hline Stock Return & -0.31 & -0.30 & -0.77 & 0.22 & 0.79 & 2.12 & -2.47 \\
\hline Stock Volatility & 0.08 & 0.08 & 0.06 & 0.10 & 0.02 & 0.14 & 0.03 \\
\hline Trading Turnover & 10.13 & 2.77 & 1.22 & 6.29 & 42.01 & 334.2 & 0.05 \\
\hline \multicolumn{8}{|c|}{ Panel B: Board and CEO Characteristics } \\
\hline Board Size & 7.57 & 7.00 & 6.00 & 9.00 & 2.30 & 19.00 & 3.00 \\
\hline Fraction of Outsiders & 0.47 & 0.50 & 0.44 & 0.50 & 0.14 & 0.86 & 0.23 \\
\hline \# of Firms with Duality & 196 & & & & & & \\
\hline CEO Ownership & 0.22 & 0.15 & 0.02 & 0.31 & 0.24 & 1.00 & 0.00 \\
\hline CEO Age (Years) & 47.81 & 47.00 & 40.00 & 54.00 & 10.37 & 79.00 & 21.00 \\
\hline CEO Tenure & 11.22 & 10.63 & 5.15 & 15.59 & 7.62 & 39.59 & 0.29 \\
\hline CEO Age $>60$ & 58 & & & & & & \\
\hline \multicolumn{8}{|c|}{ Panel C: Ownership Characteristics (\%) } \\
\hline Pre-IPO Promoters' Holding & 83.05 & 89.14 & 69.86 & 100.00 & 19.36 & 100.00 & 23.55 \\
\hline Post-IPO Promoters' Holding & 58.62 & 59.22 & 49.38 & 69.09 & 15.73 & 90.04 & 20.25 \\
\hline Top Promoter & 41.35 & 36.24 & 23.39 & 55.75 & 23.37 & 100.00 & 4.10 \\
\hline Institutional Ownership - IPO & 14.09 & 12.87 & 7.07 & 19.13 & 9.64 & 55.21 & 0.00 \\
\hline Institutional Ownership - Qtr 1 & 10.09 & 8.72 & 2.72 & 15.00 & 9.19 & 49.80 & 0.00 \\
\hline Institutional Ownership - Qtr 2 & 10.25 & 8.69 & 1.58 & 14.78 & 9.66 & 49.52 & 0.00 \\
\hline Institutional Ownership - Qtr 3 & 10.32 & 8.82 & 1.84 & 15.62 & 10.03 & 52.25 & 0.00 \\
\hline Institutional Ownership - Qtr 4 & 10.31 & 8.67 & 1.36 & 15.90 & 10.17 & 52.07 & 0.00 \\
\hline
\end{tabular}

The table reports the descriptive statistics of Indian IPO characteristics and board characteristics. The sample includes IPOs listed on the BSE and NSE from January 2004 to December 2012. All the variables are defined in Appendix A. 
Table 2: The Determinants of Board Size

\begin{tabular}{|c|c|c|c|c|}
\hline & $\begin{array}{l}\text { Advising } \\
\text { (1) }\end{array}$ & $\begin{array}{l}\text { Monitoring } \\
\text { (2) }\end{array}$ & $\begin{array}{l}\text { CEO } \\
(3)\end{array}$ & $\begin{array}{l}\text { All } \\
(4)\end{array}$ \\
\hline Total Assets & $\begin{array}{c}0.622 * * * \\
(6.04)\end{array}$ & & & $\begin{array}{c}0.519 * * * \\
(5.30)\end{array}$ \\
\hline Firm Age & $\begin{array}{c}0.107 * * \\
(2.01)\end{array}$ & & & $\begin{array}{l}0.084^{*} \\
(1.87)\end{array}$ \\
\hline Debt & $\begin{array}{l}-0.099 \\
(-0.14)\end{array}$ & & & $\begin{array}{l}-0.077 \\
(-0.11)\end{array}$ \\
\hline Cash holdings & & $\begin{array}{c}0.443 * * \\
(2.13)\end{array}$ & & $\begin{array}{c}0.301 * * \\
(2.02)\end{array}$ \\
\hline Market-to-Book & & $\begin{array}{l}-0.006 \\
(-0.05)\end{array}$ & & $\begin{array}{l}-0.075 \\
(-0.54)\end{array}$ \\
\hline CEO Ownership & & $\begin{array}{c}-0.027 * * * \\
(-5.73)\end{array}$ & $\begin{array}{c}-0.026 * * * \\
(-5.85)\end{array}$ & $\begin{array}{c}-0.017 * * * \\
(-3.99)\end{array}$ \\
\hline ROA & & & $\begin{array}{l}0.010 \\
(0.01)\end{array}$ & $\begin{array}{l}0.090 \\
(0.08)\end{array}$ \\
\hline CEO Tenure & & & $\begin{array}{l}-0.179 \\
(-1.26)\end{array}$ & $\begin{array}{l}-0.125 \\
(-0.92)\end{array}$ \\
\hline CEO Age & & & $\begin{array}{l}-0.001 \\
(-0.07)\end{array}$ & $\begin{array}{l}-0.012 \\
(-0.85)\end{array}$ \\
\hline CEO Age $>60$ & & & $\begin{array}{c}1.080 * * \\
(2.12)\end{array}$ & $\begin{array}{c}0.990 * * \\
(2.03)\end{array}$ \\
\hline Industry \& Year Dummies & Yes & & Yes & Yes \\
\hline Constant & $\begin{array}{l}1.522^{*} \\
(1.94)\end{array}$ & $\begin{array}{c}6.889 * * * \\
(16.21)\end{array}$ & $\begin{array}{c}6.951 * * * \\
(9.03)\end{array}$ & $\begin{array}{c}3.608 * * * \\
(3.63)\end{array}$ \\
\hline $\begin{array}{l}\text { Observations } \\
\text { Adjusted } R 2\end{array}$ & $\begin{array}{c}377 \\
0.138\end{array}$ & $\begin{array}{c}377 \\
0.095\end{array}$ & $\begin{array}{c}377 \\
0.109\end{array}$ & $\begin{array}{c}377 \\
0.236\end{array}$ \\
\hline
\end{tabular}

This Table shows the OLS regression results of the determinants of board size. The dependent variable in all the specifications is size of the board. The sample includes IPOs listed on the BSE and NSE from January 2004 to December 2012. All the variables are defined in Appendix A. White heteroskedasticity-consistent tstatistics are in parentheses. $* \mathrm{p}<0.10, * * \mathrm{p}<0.05, * * * \mathrm{p}<0.01$ 
Table 3: The Determinants of Board Independence

\begin{tabular}{|c|c|c|c|c|}
\hline & $\begin{array}{c}\text { Advising } \\
\text { (1) }\end{array}$ & $\begin{array}{l}\text { Monitoring } \\
\text { (2) }\end{array}$ & $\begin{array}{l}\text { CEO } \\
\text { (3) }\end{array}$ & $\begin{array}{l}\text { All } \\
(4)\end{array}$ \\
\hline Total Assets & $\begin{array}{c}0.271 * * * \\
(4.36)\end{array}$ & & & $\begin{array}{c}0.239 * * * \\
(3.72)\end{array}$ \\
\hline Firm Age & $\begin{array}{l}0.100^{*} \\
(1.76)\end{array}$ & & & $\begin{array}{l}0.082 \\
(0.57)\end{array}$ \\
\hline Debt & $\begin{array}{l}-0.330 \\
(-0.88)\end{array}$ & & & $\begin{array}{l}-0.325 \\
(-0.77)\end{array}$ \\
\hline Cash holdings & & $\begin{array}{l}0.219^{*} \\
(1.79)\end{array}$ & & $\begin{array}{c}0.392 * * * \\
(2.68)\end{array}$ \\
\hline Market-to-Book & & $\begin{array}{l}0.042 \\
(0.62)\end{array}$ & & $\begin{array}{l}0.042 \\
(0.55)\end{array}$ \\
\hline CEO Ownership & & $\begin{array}{c}-0.010 * * * \\
(-3.29)\end{array}$ & $\begin{array}{c}-0.010 * * * \\
(-3.43)\end{array}$ & $\begin{array}{c}-0.006^{* *} \\
(-2.26)\end{array}$ \\
\hline ROA & & & $\begin{array}{l}0.415 \\
(0.72)\end{array}$ & $\begin{array}{l}0.440 \\
(0.76)\end{array}$ \\
\hline CEO Tenure & & & $\begin{array}{l}-0.078 \\
(-0.82)\end{array}$ & $\begin{array}{l}-0.073 \\
(-0.75)\end{array}$ \\
\hline CEO Age & & & $\begin{array}{l}-0.007 \\
(-0.65)\end{array}$ & $\begin{array}{l}-0.013 \\
(-1.30)\end{array}$ \\
\hline CEO Age $>60$ & & & $\begin{array}{l}0.625^{*} \\
(1.89)\end{array}$ & $\begin{array}{l}0.603^{*} \\
(1.83)\end{array}$ \\
\hline Industry \& Year Dummies & Yes & & Yes & Yes \\
\hline Constant & $\begin{array}{l}0.627 \\
(0.87)\end{array}$ & $\begin{array}{c}2.822 * * * \\
(5.46)\end{array}$ & $\begin{array}{c}3.066^{* * *} \\
(4.46)\end{array}$ & $\begin{array}{l}1.613^{*} \\
(1.87)\end{array}$ \\
\hline $\begin{array}{l}\text { Observations } \\
\text { Adjusted } R 2\end{array}$ & $\begin{array}{c}377 \\
0.080\end{array}$ & $\begin{array}{c}377 \\
0.058\end{array}$ & $\begin{array}{c}377 \\
0.061\end{array}$ & $\begin{array}{c}377 \\
0.098\end{array}$ \\
\hline
\end{tabular}

This Table shows the OLS regression results for the determinants of board independence. The dependent variable in all the specifications is the number of outsiders on the board. All the variables are defined in Appendix A. White heteroskedasticity-consistent t-statistics are in parentheses. ${ }^{*} \mathrm{p}<0.10, * * \mathrm{p}<0.05,{ }^{*} * * \mathrm{p}<0.01$. 
Table 4: Board Structure \& Institutional Holdings - OLS Regressions

\begin{tabular}{|c|c|c|c|}
\hline & $\begin{array}{c}\text { Qtr 1 } \\
(1)\end{array}$ & $\begin{array}{c}\text { Qtr } 2 \\
\text { (3) }\end{array}$ & $\begin{array}{c}\text { Qtr } 4 \\
\text { (3) }\end{array}$ \\
\hline Board Independence & $\begin{array}{l}1.476 \\
(0.27)\end{array}$ & $\begin{array}{l}0.882 \\
(0.16)\end{array}$ & $\begin{array}{l}2.690 \\
(0.46)\end{array}$ \\
\hline Board Size & $\begin{array}{l}0.021 \\
(0.09)\end{array}$ & $\begin{array}{l}-0.092 \\
(-0.38)\end{array}$ & $\begin{array}{l}-0.164 \\
(-0.69)\end{array}$ \\
\hline Dual & $\begin{array}{l}-0.696 \\
(-0.76)\end{array}$ & $\begin{array}{l}0.009 \\
(0.01)\end{array}$ & $\begin{array}{l}-0.568 \\
(-0.62)\end{array}$ \\
\hline Top Promoter & $\begin{array}{l}-0.014 \\
(-0.79)\end{array}$ & $\begin{array}{l}-0.011 \\
(-0.62)\end{array}$ & $\begin{array}{l}-0.010 \\
(-0.52)\end{array}$ \\
\hline Post-IPO Promoters' Holding & $\begin{array}{c}-13.562 * * * \\
(-4.09)\end{array}$ & $\begin{array}{c}-15.035^{* * *} \\
(-4.14)\end{array}$ & $\begin{array}{c}-13.390 * * * \\
(-3.66)\end{array}$ \\
\hline VC Backed & $\begin{array}{l}1.967 \\
(1.24)\end{array}$ & $\begin{array}{l}3.093^{*} \\
(1.92)\end{array}$ & $\begin{array}{l}2.572 \\
(1.59)\end{array}$ \\
\hline Market Capitalization & $\begin{array}{c}2.456 * * * \\
(5.41)\end{array}$ & $\begin{array}{c}2.324 * * * \\
(4.96)\end{array}$ & $\begin{array}{c}1.833 * * * \\
(3.78)\end{array}$ \\
\hline Book-to-Market & $\begin{array}{l}-0.531 \\
(-0.75)\end{array}$ & $\begin{array}{l}-0.482 \\
(-0.64)\end{array}$ & $\begin{array}{l}-0.862 \\
(-1.03)\end{array}$ \\
\hline Firm Age & $\begin{array}{l}0.330 \\
(0.41)\end{array}$ & $\begin{array}{l}0.311 \\
(0.38)\end{array}$ & $\begin{array}{l}0.514 \\
(0.63)\end{array}$ \\
\hline ROA & $\begin{array}{l}-2.889 \\
(-1.10)\end{array}$ & $\begin{array}{l}-2.105 \\
(-0.76)\end{array}$ & $\begin{array}{l}-2.237 \\
(-0.67)\end{array}$ \\
\hline Cash & $\begin{array}{c}8.839 * * * \\
(5.99)\end{array}$ & $\begin{array}{c}9.946 * * * \\
(4.71)\end{array}$ & $\begin{array}{c}9.688 * * * \\
(4.31)\end{array}$ \\
\hline Debt & $\begin{array}{l}-1.971 \\
(-0.72)\end{array}$ & $\begin{array}{l}-2.209 \\
(-0.81)\end{array}$ & $\begin{array}{l}-3.237 \\
(-1.18)\end{array}$ \\
\hline Stock Return & $\begin{array}{l}0.159 \\
(0.74)\end{array}$ & $\begin{array}{c}0.829 * * \\
(2.23)\end{array}$ & $\begin{array}{c}3.098 * * * \\
(4.77)\end{array}$ \\
\hline Stock Volatility & $\begin{array}{c}-15.530 \\
(-1.17)\end{array}$ & $\begin{array}{c}-42.293^{* *} \\
(-2.46)\end{array}$ & $\begin{array}{c}-77.482 * * * \\
(-3.05)\end{array}$ \\
\hline Trading Turnover & $\begin{array}{c}-1.402 * * * \\
(-3.80)\end{array}$ & $\begin{array}{c}-0.012 * * \\
(-2.36)\end{array}$ & $\begin{array}{l}-0.009 \\
(-1.47)\end{array}$ \\
\hline Industry \& Year Dummies & Yes & Yes & Yes \\
\hline Constant & -4.320 & -0.223 & 4.300 \\
\hline
\end{tabular}




\begin{tabular}{lccc} 
& $(-0.79)$ & $(-0.04)$ & $(0.73)$ \\
\hline Observations & 345 & 345 & 345 \\
Adjusted $R 2$ & 0.262 & 0.329 & 0.352 \\
\hline
\end{tabular}

This Table reports the OLS regression results of the influence of board structure on institutional holdings in IPOs. The dependent variable in specifications (1), (2), and (3) is institutional ownership at the end of the first, second and fourth quarter respectively. All the variables are defined in Appendix A. White heteroskedasticity-consistent t-statistics are in parentheses. $* \mathrm{p}<0.10, * * \mathrm{p}<0.05, * * * \mathrm{p}<0.01$. 


\begin{tabular}{|c|c|c|c|c|c|c|}
\hline & $\begin{array}{l}\text { Dom Qtr } 1 \\
\text { (1) }\end{array}$ & $\begin{array}{c}\text { Dom Qtr } 2 \\
\text { (2) }\end{array}$ & $\begin{array}{l}\text { Dom Qtr } 3 \\
\text { (3) }\end{array}$ & $\begin{array}{l}\text { For Qtr } 1 \\
\text { (4) }\end{array}$ & $\begin{array}{c}\text { For Qtr } 2 \\
\quad(5)\end{array}$ & $\begin{array}{c}\text { For Qtr } 3 \\
\text { (6) }\end{array}$ \\
\hline Board Independence & $\begin{array}{l}-5.305 \\
(-1.21)\end{array}$ & $\begin{array}{l}-5.515 \\
(-1.03)\end{array}$ & $\begin{array}{l}-3.705 \\
(-0.89)\end{array}$ & $\begin{array}{l}5.523^{* * *} \\
(2.34)\end{array}$ & $\begin{array}{l}\text { 6.487** } \\
(2.51)\end{array}$ & $\begin{array}{l}6.870 * * \\
(2.54)\end{array}$ \\
\hline Board Size & $\begin{array}{l}0.076 \\
(0.55)\end{array}$ & $\begin{array}{l}0.074 \\
(0.52)\end{array}$ & $\begin{array}{l}0.048 \\
(0.35)\end{array}$ & $\begin{array}{l}-0.028 \\
(-0.16)\end{array}$ & $\begin{array}{l}-0.144 \\
(-0.79)\end{array}$ & $\begin{array}{l}-0.170 \\
(-0.93)\end{array}$ \\
\hline Dual & $\begin{array}{l}0.399 \\
(0.72)\end{array}$ & $\begin{array}{l}0.619 \\
(1.13)\end{array}$ & $\begin{array}{l}0.597 \\
(1.13)\end{array}$ & $\begin{array}{l}-0.790 \\
(-1.25)\end{array}$ & $\begin{array}{l}-0.457 \\
(-0.70)\end{array}$ & $\begin{array}{l}-1.000 \\
(-1.46)\end{array}$ \\
\hline Top Promoter & $\begin{array}{l}-0.015 \\
(-1.28)\end{array}$ & $\begin{array}{l}-0.011 \\
(-0.97)\end{array}$ & $\begin{array}{l}-0.010 \\
(-0.85)\end{array}$ & $\begin{array}{l}0.001 \\
(0.09)\end{array}$ & $\begin{array}{l}0.000 \\
(0.03)\end{array}$ & $\begin{array}{l}0.002 \\
(0.15)\end{array}$ \\
\hline Post-IPO Promoters' Holding & $\begin{array}{l}-4.459 * * \\
(-2.18)\end{array}$ & $\begin{array}{l}-5.004 * * \\
(-2.39)\end{array}$ & $\begin{array}{l}-4.679 * * \\
(-2.29)\end{array}$ & $\begin{array}{l}-8.564 * * * \\
(-3.16)\end{array}$ & $\begin{array}{l}-9.132 * * * \\
(-2.99)\end{array}$ & $\begin{array}{l}-9.014 * * * \\
(-3.14)\end{array}$ \\
\hline VC Backed & $\begin{array}{l}0.670 \\
(0.71)\end{array}$ & $\begin{array}{l}0.543 \\
(0.57)\end{array}$ & $\begin{array}{l}0.627 \\
(0.68)\end{array}$ & $\begin{array}{l}1.117 \\
(0.93)\end{array}$ & $\begin{array}{l}2.224^{*} \\
(1.74)\end{array}$ & $\begin{array}{l}1.942 \\
(1.53)\end{array}$ \\
\hline Market Capitalization & $\begin{array}{l}0.482 \\
(1.63)\end{array}$ & $\begin{array}{l}0.492^{*} \\
(1.68)\end{array}$ & $\begin{array}{l}0.439 \\
(1.52)\end{array}$ & $\begin{array}{l}1.692 * * * \\
(4.94)\end{array}$ & $\begin{array}{l}1.604 * * * \\
(4.46)\end{array}$ & $\begin{array}{l}1.372 * * * \\
(3.96)\end{array}$ \\
\hline Book-to-Market & $\begin{array}{l}-0.175 \\
(-0.41)\end{array}$ & $\begin{array}{l}-0.115 \\
(-0.27)\end{array}$ & $\begin{array}{l}-0.119 \\
(-0.31)\end{array}$ & $\begin{array}{l}-0.344 \\
(-0.66)\end{array}$ & $\begin{array}{l}-0.318 \\
(-0.59)\end{array}$ & $\begin{array}{l}-0.633 \\
(-0.98)\end{array}$ \\
\hline Firm Age & $\begin{array}{l}0.346 \\
(0.72)\end{array}$ & $\begin{array}{l}0.514 \\
(1.04)\end{array}$ & $\begin{array}{l}0.761 \\
(1.51)\end{array}$ & $\begin{array}{l}0.125 \\
(0.21)\end{array}$ & $\begin{array}{l}-0.087 \\
(-0.13)\end{array}$ & $\begin{array}{l}-0.147 \\
(-0.23)\end{array}$ \\
\hline ROA & $\begin{array}{l}0.677 \\
(0.59)\end{array}$ & $\begin{array}{l}0.786 \\
(0.65)\end{array}$ & $\begin{array}{l}-0.187 \\
(-0.13)\end{array}$ & $\begin{array}{l}-3.423 \\
(-1.51)\end{array}$ & $\begin{array}{l}-2.937 \\
(-1.14)\end{array}$ & $\begin{array}{l}-1.911 \\
(-0.63)\end{array}$ \\
\hline Cash & $\begin{array}{l}10.065^{* * *} \\
(3.61)\end{array}$ & $\begin{array}{l}11.912 * * * \\
(3.83)\end{array}$ & $\begin{array}{l}12.345^{* * *} \\
(3.64)\end{array}$ & $\begin{array}{l}1.880 \\
(1.05)\end{array}$ & $\begin{array}{l}2.600 * \\
(1.75)\end{array}$ & $\begin{array}{l}2.715^{*} \\
(1.78)\end{array}$ \\
\hline Debt & $\begin{array}{l}-1.092 \\
(-0.76)\end{array}$ & $\begin{array}{l}-1.700 \\
(-1.16)\end{array}$ & $\begin{array}{l}-2.036 \\
(-1.38)\end{array}$ & $\begin{array}{l}-1.428 \\
(-0.72)\end{array}$ & $\begin{array}{l}-1.234 \\
(-0.62)\end{array}$ & $\begin{array}{l}-1.227 \\
(-0.59)\end{array}$ \\
\hline Stock Return & $\begin{array}{l}0.505 \\
(1.36)\end{array}$ & $\begin{array}{l}0.455 \\
(1.22)\end{array}$ & $\begin{array}{l}0.782 \\
(1.18)\end{array}$ & $\begin{array}{l}0.566^{*} \\
(1.81)\end{array}$ & $\begin{array}{l}1.364 * * * \\
(3.36)\end{array}$ & $\begin{array}{l}2.196^{* * * *} \\
(4.65)\end{array}$ \\
\hline Stock Volatility & $\begin{array}{l}-34.452^{* *} \\
(-2.32)\end{array}$ & $\begin{array}{l}-42.492 * * * \\
(-2.95)\end{array}$ & $\begin{array}{l}-48.613 * * * \\
(-3.67)\end{array}$ & $\begin{array}{l}-11.042 \\
(-0.65)\end{array}$ & $\begin{array}{l}-36.042 * * \\
(-2.16)\end{array}$ & $\begin{array}{l}-29.173^{*} \\
(-1.67)\end{array}$ \\
\hline Trading Turnover & $\begin{array}{l}-0.011 * * * \\
(-4.37)\end{array}$ & $\begin{array}{l}-0.009 * * * \\
(-3.69)\end{array}$ & $\begin{array}{l}-0.006^{* *} \\
(-2.21)\end{array}$ & $\begin{array}{l}-0.005^{* *} \\
(-2.21)\end{array}$ & $\begin{array}{l}-0.003 \\
(-0.46)\end{array}$ & $\begin{array}{l}-0.003 \\
(-0.41)\end{array}$ \\
\hline Industry \& Year Dummies & Yes & Yes & Yes & Yes & Yes & Yes \\
\hline
\end{tabular}




\begin{tabular}{lllllll} 
Constant & $7.710^{* *}$ & $7.490^{* *}$ & $7.338^{* *}$ & $-7.162^{* *}$ & -3.949 & -2.388 \\
& $(2.09)$ & $(2.04)$ & $(2.02)$ & $(-2.11)$ & $(-1.15)$ & $(-0.65)$ \\
\hline Observations & 345 & 345 & 345 & 360 & 360 & 360 \\
Adjusted $R 2$ & 0.230 & 0.265 & 0.277 & 0.196 & 0.274 & 0.272 \\
\hline
\end{tabular}

This Table reports the OLS regression results of the influence of board structure on domestic and foreign institutional holdings in IPOs. The dependent variable in specifications (1), (2) and (3) is domestic institutional ownership at the end of the first, second and fourth quarter respectively. The dependent variable in specifications (4), (5) and (6) is foreign institutional ownership at the end of the first, second and fourth quarter respectively. For a definition of variables see Appendix A. White heteroskedasticity-consistent tstatistics are in parentheses. ${ }^{*} \mathrm{p}<0.10, * * \mathrm{p}<0.05, * * * \mathrm{p}<0.01$ 